\section{Pythium Root Rot Resistance in Commercial Caladium Cultivars}

\author{
Zhanao Deng, ${ }^{1}$ Brent K. Harbaugh, ${ }^{2}$ and Rick O. Kelly ${ }^{2}$ \\ University of Florida, Institute of Food and Agricultural Sciences, Gulf Coast \\ Research and Education Center, 5007 60th Street East, Bradenton, FL 34203
}

\author{
Teresa Seijo ${ }^{3}$ \\ University of Florida, Institute of Food and Agricultural Sciences, Gulf \\ Coast Research and Education Center-Dover, 13138 Lewis Gallagher Road, \\ Dover, FL 33527
}

\section{Robert J. McGovern ${ }^{4}$ \\ University of Florida, Doctor of Plant Medicine Degree Program, 1453 Fifield Hall, Gainesville, FL 32611}

Additional index words. Araceace, Caladium $\times$ hortulanum, germplasm, disease resistance, plant breeding

\begin{abstract}
Caladiums (Caladium $\times$ hortulanum) are popular ornamental plants widely grown for their bright colorful leaves. Pythium root rot, caused by Pythium myriotylum, is one of the few soil-borne diseases in caladium that dramatically reduces plant growth, aesthetic value, and tuber yield. Information on the reaction of caladium cultivars to $P$. myriotylum is not available, but would be valuable for integrated control of this disease and for breeding new resistant cultivars. Three Pythium isolates obtained from decaying roots of plants collected from a field production site and two greenhouses were evaluated for pathogenicity and potential use in experiments to screen commercial caladium cultivars for resistance. All three isolates were found to be highly virulent; they were able to cause obvious root rotting within 3 to 5 days and severe root rotting and leaf losses on susceptible cultivars within 10 days after inoculation. Nineteen major commercial cultivars were evaluated for their resistance to these isolates. Fifteen of the cultivars were susceptible or highly susceptible to Pythium infection. Four widely grown cultivars, 'Candidum', 'Candidum Jr.', 'Frieda Hemple', and 'White Christmas', were found to have a moderate level of resistance (partial resistance) to pythium root rot. Pythium infection also caused leaf discoloration, epinasty, wilting, and collapse. Regression analyses revealed a linear relationship between the root rot and leaf loss severity on Pythium-inoculated plants.
\end{abstract}

Caladiums (Caladium $\times$ hortulanum Birdsey) are popular ornamental plants grown in containers, hanging baskets, or used for landscaping (Wilfret, 1993). They possess a number of favorable characteristics, including bright colorful leaves, excellent tolerance to shade and heat, and ease in growing, that attract greenhouse growers, nurseries, and home gardeners. Commercially available caladium plants are forced in containers from tubers; over $95 \%$ of the caladium tubers grown in the world are produced in Central Florida (Bell et al., 1998).

Aproblem in caladium production has been root rot, which is caused by Pythium myriotylum Drechs., although P. irregulare Buis. and $P$. spelendens were also isolated from infected caladium roots (Ridings and Hartman, 1976). Caladium tubers infected with $P$. myriotylum are 3 to 5 weeks slower to sprout, have up to

\footnotetext{
Received for publication 23 July 2004. Accepted for publication 12 Oct. 2004. Florida Agricultural Experiment Station Journal Series R-10369. We thank Nancy West, Joyce Jones, and Gail Bowman for their excellen technical support. This research was funded in part by grants from theFlorida Caladium Growers'Association. We appreciate R. Hartman's generous donation of tissue cultured caladium plants for this study.

${ }^{1}$ To whom reprint requests should be addressed; e-mail zdeng@mail.ifas.ufl.edu.
}

$70 \%$ reduced plant growth, and suffer from tuber loss of up to $40 \%$ (Chase, 1987; Ridings and Hartman, 1976). Pythium infection may also create favorable conditions for other soil-borne pathogens to enter caladium roots or tubers. In peanut, P. myriotylum acts synergistically with Fusarium solani and root-knot nematodes (Garcia and Mitchell, 1975), both of which are major pests to caladium tuber production (Esser 1973; Knauss 1975).

Use of disease resistant cultivars has proven to be an important and economically viable strategy for integrated management of major diseases in crops and for reducing the use of pesticides. This strategy is particularly useful for caladiums and other ornamental plants in the landscape and home gardens, because in such cases choices of root rot control measures are limited. We recently initiated a breeding program for developing caladium cultivars resistant to pythium rootrot. However, no identified sources of resistance are available, and information on caladium cultivars' reaction to this pathogen is lacking. The objectives of this study were 1) to identify virulent Pythium isolates and develop screening procedures for resistance evaluation, and 2) to evaluate major commercial cultivars for their resistance to pythium root rot, and thus identify potential sources of resistance for use in breeding of new resistant varieties.
Caladium plants. Caladium plants used in this study (except for 'Texas Beauty') were derived from tissue culture. The plants had been micropropagated from shoot tips using a procedure modified from Hartman (1974). The donated plants, about 2 to 3 months old and grown in seedling flats, were further increased in greenhouses at Bradenton, Fla. to obtain the required numbers of plants for inoculation experiments. No tissue culture plants were available for 'Texas Beauty', so the plants used in this study were grown from tubers produced in sandy soil under field conditions at Bradenton, Fla. For all plants, propagation was achieved by dividing young tubers ( 1.5 to $3 \mathrm{~cm}$ in diameter) into smaller pieces, each with one sprout or one obvious bud at the dividing time, and growing these pieces in six-pack plastic cells. Cells of the six-pack were $3.5 \times 3.5 \times 5.5 \mathrm{~cm}$ at top brim (approximately $45 \mathrm{~mL}$ in volume) and were filled with course vermiculite amended with Nutricote 13-13-13 (13N-6.4P-10.8K; The Scotts Co., Marysville, Ohio) at a rate of 7 to 9 granules/cell. Plants were grown on benches in a shaded glass greenhouse with $20 \%$ to $30 \%$ light exclusion, a photosynthetic photon flux ranging from 600 to $800 \mu \mathrm{mol} \cdot \mathrm{m}^{-2} \cdot \mathrm{s}^{-1}$, under a natural photoperiod at Bradenton, FL. Irrigation was provided with an intermittent mist system, and the temperature was maintained in a range of 21 to $32{ }^{\circ} \mathrm{C}$ with cooling pads and fans. Plants used for studies were about 8 weeks old, 15 to $30 \mathrm{~cm}$ tall, with three to six leaves. Three plants were grown in each six-pack cell.

Pythium isolates and inoculum preparation. The three P. myriotylum isolates-97-439B, $\mathrm{P} 1$, and $\mathrm{P} 2$ - used in this study originated from rotting roots of field-grown caladium plants in 1997, or from greenhouse-grown potted plants in 2002, and 2003, respectively. For inoculum production, isolates were grown on $1 / 4$ APDA (acidified potato dextrose agar medium) at 31 ${ }^{\circ} \mathrm{C}$ in the dark for $24 \mathrm{~h}$. Five small agar plugs $(5 \times 5 \mathrm{~mm})$ from the leading edge of fungal growth were transferred into each petri dish. The dish was filled to the top of the plugs with V8 broth. The broth was made by mixing 350 mL V8 juice (Campbell's Soup Co., Cadmen, N.J.) and $5 \mathrm{~g} \mathrm{CaCO}_{3}$, filtering through a coffee filter, and then diluting $250 \mathrm{~mL}$ with water into $1 \mathrm{~L}$ final volume before autoclaving. Mycelial mats were produced by incubating the plates at $31{ }^{\circ} \mathrm{C}$ in the dark overnight. The mats were washed with sterile deionized water three times, flooded in sterile water, and incubated at room temperature for $48 \mathrm{~h}$ under cool-white fluorescent lights. The mats were blended in a clean blender on high for $2 \mathrm{~min}$ and then filtered through a four-ply layer of sterile cheesecloth to collect oospores. Density of oospores in the resultant suspension was determined using a hemacytometer, and the desired levels of spores were achieved by diluting with sterile deionized water before the suspension was used in artificial inoculations.

Inoculation, disease development, and resistance evaluation. Experiments were per- 
Table 1. Disease severity for19 major commercial caladium cultivars inoculated with 3 virulent and aggressive Pythium isolates.

\begin{tabular}{|c|c|c|c|c|c|c|c|c|c|}
\hline \multirow[b]{2}{*}{ Cultivar } & \multirow{2}{*}{$\begin{array}{l}\text { Leaf shape } \\
\text { and color }\end{array}$} & \multirow[b]{2}{*}{ Parentage } & \multicolumn{4}{|c|}{ Root rot rating ${ }^{z}$} & \multicolumn{3}{|c|}{ Plant leaf loss rating $^{y}$} \\
\hline & & & Expt. 2 & Expt. 3 & $\operatorname{Avg}^{x}$ & Categoryw $^{w}$ & Expt. 2 & Expt. 3 & $\operatorname{Avg}^{x}$ \\
\hline Frieda Hemple & Fancy red & Unknown & 4.8 & 4.1 & $4.4 \mathrm{a}$ & MR & 4.4 & 4.1 & $4.2 \mathrm{a}$ \\
\hline Candidum & Fancy white & Unknown & 4.6 & 4.0 & $4.3 \mathrm{a}$ & MR & 4.5 & 3.5 & $4.0 \mathrm{a}$ \\
\hline Candidum Jr. & Fancy white & Unknown & 3.9 & 4.1 & $4.0 \mathrm{ab}$ & MR & 4.1 & 3.8 & $4.0 \mathrm{a}$ \\
\hline White Christmas & Fancy white & Unknown & 3.9 & 4.0 & $4.0 \mathrm{a}-\mathrm{c}$ & MR & 4.0 & 3.5 & $3.8 \mathrm{a}-\mathrm{c}$ \\
\hline Carolyn Whorton & Fancy pink & Unknown & 3.5 & 4.0 & $3.8 \mathrm{a}-\mathrm{d}$ & $\mathrm{S}$ & 3.8 & 4.1 & $4.0 \mathrm{a}$ \\
\hline Florida Fantasy & Fancy multicolor & Candidum $\mathrm{Jr} \times$ Red Frill & 4.0 & 2.8 & $3.4 \mathrm{~b}-\mathrm{e}$ & $\mathrm{S}$ & 3.8 & 2.7 & $3.3 \mathrm{~cd}$ \\
\hline Florida Elise & Fancy pink & $\begin{array}{l}\text { Carolyn Whorton } \times \\
\text { (Carolyn Whorton } \times \text { Candidum) }\end{array}$ & 3.6 & 3.0 & $3.3 b-f$ & $\mathrm{~S}$ & 3.0 & 2.7 & $2.9 \mathrm{de}$ \\
\hline Florida Red Ruffles & Lance red & $($ Red Frill $\times$ Candidum $\mathrm{Jr}) \times$ Red Frill & 3.5 & 3.0 & $3.3 \mathrm{~b}-\mathrm{f}$ & $\mathrm{S}$ & 3.8 & 3.4 & $3.6 \mathrm{a}-\mathrm{c}$ \\
\hline Florida Sweetheart & Lance pink & Candidum Jr. $\times$ Red Frill & 3.1 & 3.4 & $3.2 \mathrm{~b}-\mathrm{f}$ & $\mathrm{S}$ & 2.9 & 3.6 & $3.6 \mathrm{a}-\mathrm{c}$ \\
\hline Aaron & Fancy white & Unknown & 3.0 & 3.4 & $3.2 \mathrm{c}-\mathrm{f}$ & $\mathrm{S}$ & 3.1 & 3.3 & $3.2 \mathrm{c}-\mathrm{e}$ \\
\hline Miss Muffet & Fancy multicolor & Unknown & 3.0 & 3.0 & $3.0 \mathrm{~d}-\mathrm{f}$ & $\mathrm{S}$ & 3.4 & 3.2 & $3.3 \mathrm{~b}-\mathrm{d}$ \\
\hline Pink Beauty & Fancy pink & Unknown & 2.7 & 3.3 & $3.0 \mathrm{~d}-\mathrm{f}$ & $\mathrm{S}$ & 2.9 & 3.4 & $3.2 \mathrm{c}-\mathrm{e}$ \\
\hline Red Flash & Fancy red & Unknown & 2.6 & 3.2 & $2.9 \mathrm{e}-\mathrm{f}$ & VS & 2.8 & 2.9 & $2.9 \mathrm{de}$ \\
\hline Fannie Munnson & Fancy pink & Unknown & 3.0 & 2.6 & $2.8 \mathrm{e}-\mathrm{g}$ & VS & 3.0 & 2.8 & $2.9 \mathrm{de}$ \\
\hline Gingerland & Fancy multicolor & Unknown & 3.1 & 2.5 & $2.8 \mathrm{e}-\mathrm{g}$ & VS & 3.9 & 2.4 & $3.1 \mathrm{c}-\mathrm{e}$ \\
\hline Gray Ghost & Fancy white & Unknown & 1.9 & 3.6 & $2.8 \mathrm{e}-\mathrm{g}$ & VS & 2.0 & 3.3 & $2.7 \mathrm{de}$ \\
\hline White Queen & Fancy multicolor & Unknown & 3.2 & 2.4 & $2.8 \mathrm{e}-\mathrm{g}$ & VS & 3.5 & 2.7 & $3.1 \mathrm{c}-\mathrm{e}$ \\
\hline Texas Beauty & Fancy red & Unknown & 2.7 & 2.6 & $2.6 \mathrm{fg}$ & VS & 2.5 & 2.8 & $2.6 \mathrm{de}$ \\
\hline Red Frill & Strap red & Unknown & 1.8 & 2.3 & $2.1 \mathrm{~g}$ & VS & 2.2 & 2.8 & $2.5 \mathrm{e}$ \\
\hline
\end{tabular}

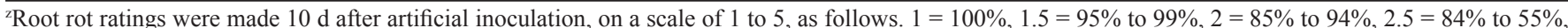

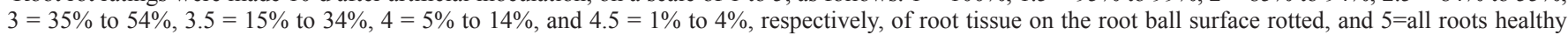
without any rotting.

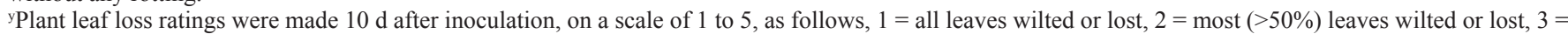
some leaves wilted (about 30\%) and showing chlorosis, $4=$ almost normal, but showing chlorosis and some stunting, and $5=$ all leaves growing normally.

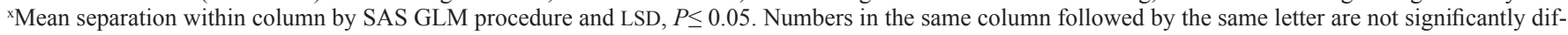
ferent using the least significant difference procedure.

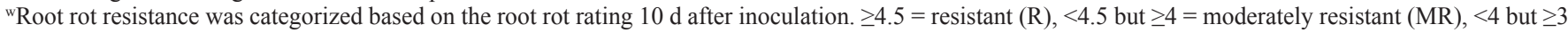
$=$ susceptible $(\mathrm{S})$, and $<3=$ very susceptible (VS).

formed in a greenhouse with environmental conditions favorable for Pythium infection and root rot development. Day and night temperatures were maintained at 30 to $37^{\circ} \mathrm{C}$ and 26 to $28^{\circ} \mathrm{C}$, respectively. Plastic saucers, one for each experimental unit, were placed on benches and connected to trickle irrigation tubes to keep continuous water saturation of the root sphere. Plants were brought into the greenhouse 2 to 3 weeks before inoculation in order to acclimatize them to growing conditions. One 6-pack with 3 plants (an experimental unit) was placed in a plastic saucer $(20 \mathrm{~cm}$ in diameter $)$ with $1.5 \mathrm{~cm}$ water. After acclimation, $5 \mathrm{~mL}$ of an oospore suspension was applied to the root media (vermiculite) surface of each plant using a Corwall continuous pipetter. Each control plant received $5 \mathrm{~mL}$ of sterile water. Inoculations were performed late in the afternoon to avoid the highest daily temperatures.

Root rotting and plant leaf losses were visually rated for each plant on a scale of 1 to 5 . For the root rot rating: $1=100 \%, 1.5$ $=95 \%$ to $99 \%, 2=85 \%$ to $94 \%, 2.5=84 \%$ to $55 \%, 3=35 \%$ to $54 \%, 3.5=15 \%$ to $34 \%$, $4=5 \%$ to $14 \%$, and $4.5=1 \%$ to $4 \%$ of root tissue on the root ball surface rotted, and $5=$ all root tissue appeared healthy without any rotting compared to the control plants. To help categorize the levels of root rot resistance, the following scale was also used: $\geq 4.5=$ resistant, $<4.5$ but $\geq 4=$ moderately resistant, $<4$ but $\geq 3=$ susceptible, and $<3$ : very susceptible. The scale for rating plant leaf losses was: $1=$ all leaves wilted or lost; $2=$ most $(>50 \%)$ leaves wilted or lost; 3 = some leaves wilted (about 30\%) and showing chlorosis; $4=$ almost normal, but showing chlorosis and some stunting; and $5=$ all leaves growing normally, compared to the control plants. After evaluation, reisolations of
Pythium were made from representative roots of rotted plants to verify the presence of the causal disease agent.

Experiment 1: Pathogenicity test. Pythium isolates 97-439B, P1, and P2 were inoculated separately on 'Florida Elise', 'Florida Fantasy', and 'Florida Red Ruffles', at a density of 1 $\times 10^{4}$ oospores $/ \mathrm{mL}$. Root rot and plant leaf losses were visually rated 10,17 , and $32 \mathrm{~d}$ after inoculation.

Experiments 2 and 3: Evaluation of commercial cultivars for resistance. Two experiments were conducted to evaluate 19 major commercially grown cultivars (Table 1). Most of these cultivars are among the top 15 grown by the caladium tuber producers and greenhouse growers (Bell et al., 1988; Deng and Harbaugh, unpublished); and they may represent the best genetic resources in $C$. $\times$ hortulatum in terms of horticultural characteristics and performance.

Oospore suspensions from the three isolates were combined before inoculation. In Expt. 2, inoculation was conducted 24 Aug. 2003 at a rate of $6 \times 10^{3}$ oospores $/ \mathrm{mL}$. Ratings were made 3 and Sept. 2003. In experiment 3, inoculation was conducted 12 Sept. using a slightly lower spore rate $\left(1 \times 10^{3}\right.$ oospores $\left./ \mathrm{mL}\right)$. Ratings were made 22 Sept. 2003.

Experiment design and statistical analysis. A randomized complete block design with five blocks was used in each experiment. Each experimental unit consisted of three plants in a six-pack (three cells with plants interspersed with three empty cells). Thus fifteen plants per genotype were inoculated for each experiment. Analysis of variance for root rot and plant leaf loss rating data were performed using the general linear model provided in SAS (PROC GLM) (SAS Institute, 2003) and treatment means were separated where appropriate. Correlation and regression analyses of root rot and leaf loss scores were performed using the PROC CORR and PROC REG procedures in SAS.

\section{Results and Discussion}

Experiment 1: Pathogenicity test. All three isolates were pathogenic and very aggressive on caladium roots of all three cultivars. There was no significant interaction of cultivar $x$ isolate so data were pooled for the cultivars (Fig. 1). Some root rotting and lesions were visible within $3 \mathrm{~d}$ after inoculation. By $10 \mathrm{~d}$ after inoculation, $30 \%$ to $75 \%$ of the caladium roots rotted, and the root rot rating on inoculated plants sharply dropped from a score of 5 at inoculation to 3.5 to about 2 (Fig. 1). Rotting continued to develop on roots and ratings continued to drop from 10 to $17 \mathrm{~d}$ after the inoculation, but at a much slower rate. After this period of time, most roots were rotted and root rot ratings seemed to change little. No significant difference was detected among the three caladium cultivars for their susceptibility to pythium root rot ( $\mathrm{F}$ value $=0.82$ to 2.28 , $P=0.13$ to 0.45 ). Although difference in the mycelial growth rate was noticeable among the isolates, no significant differences were revealed among them in inducing root rot on the three cultivars (F value $=0.24$ to $2.17, P$ $=0.79$ to 0.14 )

The importance of incorporating multiple isolates from different geographical locations in disease resistance evaluation and screening has been emphasized (Norman et al., 1999, 2003). We used three isolates that were from two different production sites and two different kinds of production facilities in this study 


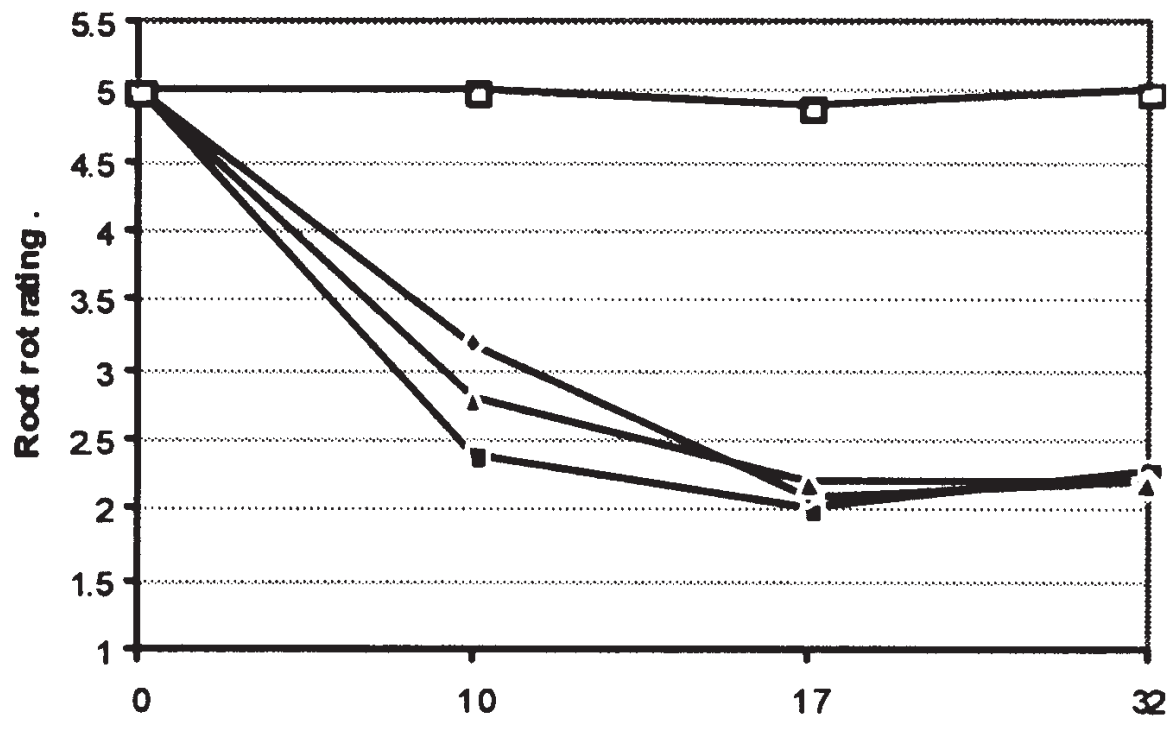

Days after inoculation

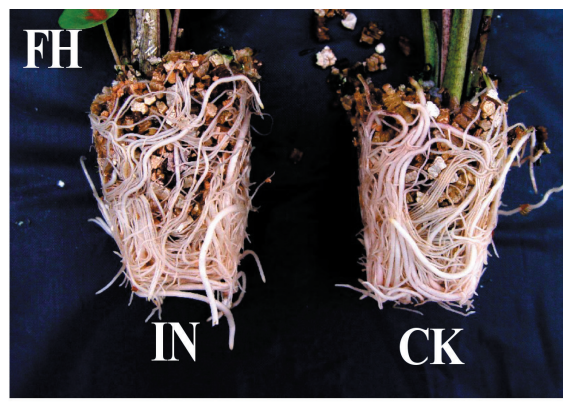

A.

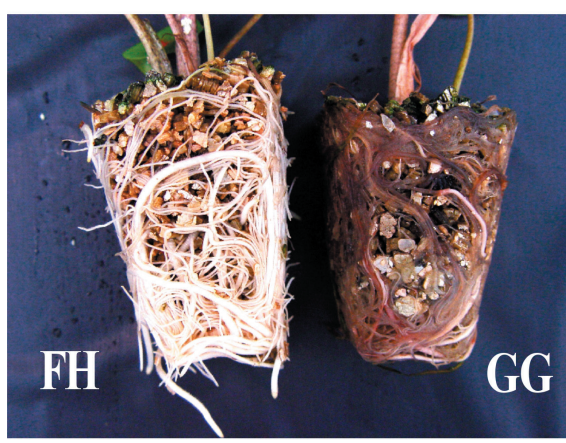

B.

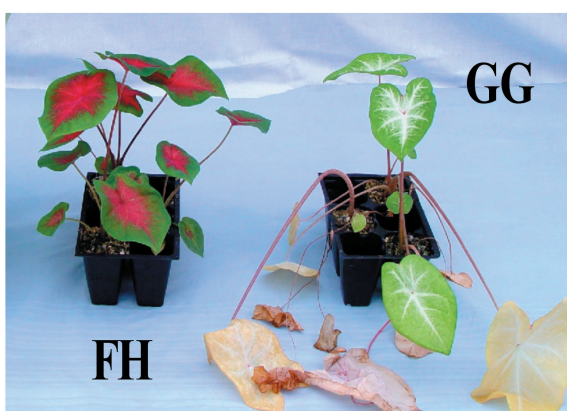

Fig. 2. (A) Roots of 'Freida Hemple' (FH) plants, inoculated with Pythium (IN) and noninoculated control (CK), $13 \mathrm{~d}$ after inoculation. (B) Roots of 'Frieda Hemple' (FH), a cultivar of moderate resistance, and 'Gray Ghost' (GG), a cultivar very susceptible to pythium root rot, $13 \mathrm{~d}$ after inoculation with Pythium. (C) Plant leaf losses on 'Gray Ghost'(GG), as compared to normal leafgrowth on 'Frieda Hemple' (FH), 13 d after inoculation.
Fig. 1. Combined root rot ratings of caladium plants (three cultivars, 'Florida Elise', 'Florida Fantasy', and 'Florida Red Ruffles') inoculated with three $P$. myriotylum isolates over a $32-\mathrm{d}$ period. $\square$ Noninoculated control plants; plants inoculated with isolate $\mathrm{P} 1 ; \boldsymbol{\Delta}$ plants inoculated with isolate P2; plants inoculated with isolate $97-$ 439B. Root rotting was visually rated on a scale of 1 to 5 . No significant differences in virulence were detected among the three isolates.

after inoculation. Four cultivars, 'Candidum', 'Candidum Jr.', 'Frieda Hemple', and 'White Christmas' had a moderate level of resistance to pythium root rot. Plants of these cultivars had only $5 \%$ to $14 \%$ of their roots rotted on the 10th day after inoculation (Fig. 2B). These plants were maintained for an extended period (6 to 7 weeks after inoculation) and were able to maintain a rating of 2.1 to 2.9 for root rot and leaf losses and kept $10 \%$ to $50 \%$ of their roots healthy. Control plants (applied with 5 mL of water to each plant instead of an oospore suspension) for each cultivar in both experiments did not show signs of rotting during the 10-d period of evaluation (Fig. 2A).

In addition to reddish lesions and rotting on roots, several leaf symptoms appeared soon after inoculation. These symptoms included tan, necrotic blotches on leaves, especially along leaf edges, yellowing on entire leaves, epinastic petioles, and leaf wilting, collapse and losses (defoliation) (Fig. 2C). These symptoms occurred as early as $3 \mathrm{~d}$ after inoculation and became more severe $7 \mathrm{~d}$ after inoculation. When a rating of plant leaf losses was made on a scale of 1 to 5 , leaf losses were correlated to the severity of root rotting (correlation coefficient $=0.84, \mathrm{n}=190, P<0.0001)$. Regression analysis showed a linear relationship between plant leaf loss and root rot severity (Fig. 3) that can be expressed as $y=0.93398+0.72328 x$, where $\mathrm{y}$ is the leaf loss rating and $\mathrm{x}$ is the root rot rating. The four cultivars that had moderate levels of resistance to root rot maintained an average leaf loss rating of 4.0, while the eight susceptible and the seven very susceptible cultivars maintained an average leaf loss rating 3.4 , and 2.8, respectively (Table 1).

Pythium root rot has been one of the few major soilborne diseases in caladium (Esser 1973; Gilreath et al., 1999; Knauss 1975). Identification, improvement, and utilization of host plant resistance to root rot are of significant importance to the various segments of the ornamental plant industry and for home gardeners that grow caladiums. The finding of moderate resistance to root rot in four of the nineteen commercial cultivars is encouraging both for caladium tuber or plant production industries and for breeding programs. Although only moderately resistant, these cultivars could serve as breeding parents for developing additional resistant cultivars in other color groups and for further improvement of root rot resistance in caladium. The likelihood of finding complete resistance (or immunity) to Pythium in caladium is low. Many soilborne plant pathogens are generally facultative and possess little parasitic specialization (GarciaE et al., 2003). Plant resistance to nonspecific pathogens is seldom high and immunity has 


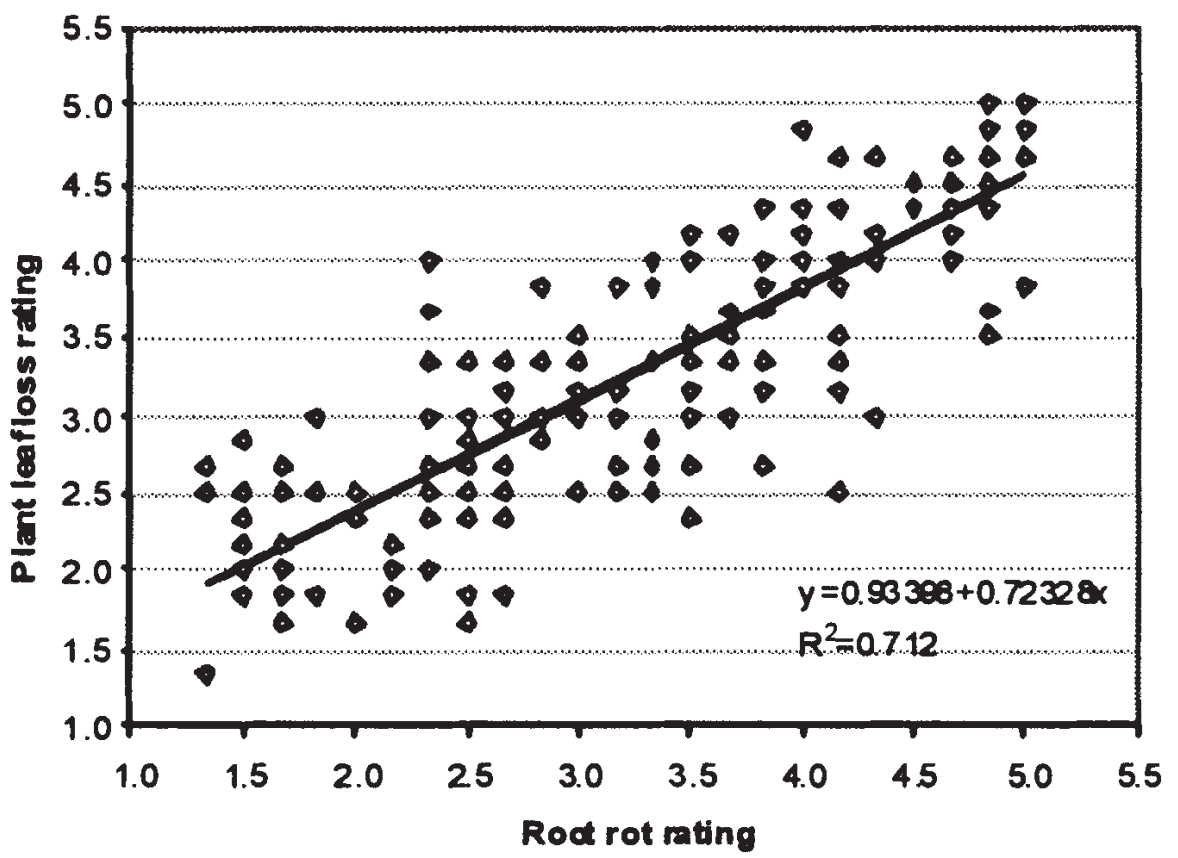

Fig. 3. Linear relationship between root rot rating scores and plant leaf loss scores on caladium plants rated $10 \mathrm{~d}$ after Pythium inoculation, as revealed by regression analyses. Root rot and leaf loss were both visually rated on a scale of 1 to 5 . The analyses were based on 190 scores $(\diamond)$ and had an $F$ value of $464.7(P \leq 0.0001)$

been rare; partial resistance or field resistance is more common to this type of pathogen (Bruehl, 1983; Johnson, 1993; Kulkarni and Baskaran, 2003). It has been shown in some crops that hybridization and subsequent recurrent selection may allow pyramiding of resistance genes involved in partial resistance in new varieties of improved resistance (Garcia-E et al., 2003).

It is intriguing that three out of the four cultivars of moderate resistance are fancyleaved and white in color. It is unknown if there is any possible genetic linkage among the leaf color, leaf shape, and Pythium resistance in caladium. This information will be valuable for designing appropriate breeding schemes to introduce the resistance to other leaf color groups. Distribution of root rot resistance among the 19 cultivars seems to be of cultivars grown. Proc. Fla. State Hort. Soc. 111:32-34.

Bruehl, G.W. 1983. Nonspecific genetic resistance to soilborne fungi. Phytopathology 73:948-951.

Chase,A.R. 1987. Compendium of ornamental foliage plant diseases. Amer. Phytopathol. Soc. Press, St. Paul, Minn.

Esser, R.P. 1973. Nematodes associated with caladium in Florida. Plant Dis. Rpt. 57:558-560.

Garcia, R. and D.J. Mitchell. 1975. Synergistic interaction of P. myriotylum with Fusarium solani, and Meloidogyne arenaria in pod rot of peanut. Phtopathology 65:832-833.

Garcia-E, R., R.A. Robinson, J.A. Aguilar-P, S. Sandoval-I, and R. Guzman-P. 2003. Recurrent selection for quantitative resistance to soil-borne diseases in beans in the Mixteca region, Mexico. Euphytica 130:241-247.

Gilreath, J.P., R. McSorley, and R.J. McGovern. 1999. Soil fumigant and herbicide combinations for soilborne pest control in caladium. Pro. Fla. State Hort. Soc. 112:285-290.

Hartman, R.D. 1974. Dasheen mosaic virus and other phytopathogens eliminated from caladium, taro, and cocoyam by culture of shoot tips. Phytopathology 64:237-240.

Johnson, R. 1993. Durability of disease resistance in crops: some closing remarks about the topic and the symposium, p. 283-300. In: Rh. Jacobs and J.E. Parlevliet (eds.). Durability of disease resistance. Kluwer Academic Publ., Dordrecht.

Knauss, J.F. 1975. Description and control of $F u$ sarium tuber rot of caladium. Plant Dis. Rpt. 59:975-979.

Kulkarni, R.N. and K. Baskaran. 2003. Inheritance of resistance to Pythium dieback in the medicinal plant periwinkle. Plant Breeding 122:184-187.

more continuous rather than discrete (Table 1 ), which may indicate that the root rot resistance is more likely to be a quantitative rather than qualitative trait. Several of the cultivars tested have known parentage, and their parents were also tested (Table 1). In some cases, the root rot scores for the progeny were between those of the parents, implying additive gene action. Further studies using controlled hybridizations are necessary to elucidate the genetics of this trait. The close correlation and linear regression between plant leaf loss and root rotting may allow development of leaf-based preliminary screening procedures for root rot resistance.

\section{Literature Cited}

Bell, M.L., G.J. Wilfret, and D.A. Devoll. 1998. Survey of caladium tuber producers for acreage
Norman, D.J., R.J. Henny, and J.M.F. Yuen. 1999. Resistance levels of pot anthurium cultivars to Xanthomonas campestris pv. dieffenbachiae. HortScience 34:721-722.

Norman, D.J., R.J. Henny, J.M.F. Yuen, and T.A. Mellich. 2003. Screening for resistance to myrothecium leaf spot among Syngonium species and cultivars. HortScience 38:75-76.

Ridings, W.H and R.D. Hartman. 1976. Pathogenicity of Pythium myriotylum and other species of Pythium to caladium derived from shoot-tip culture. Phytopathology 66:704-709.

SAS Institute. 2003. The SAS system for Windows. Release 8.02. SAS Inst., Cary, N.C.

Wilfret, G.J. 1993. Caladium, p. 239-247. In:A. DeHertogh and M. LeNard (eds.). The physiology of flower bulbs. Elsevier, Amsterdam. 